\title{
The Book of Revelation
}

\section{Currents in British Research on the Apocalypse Ed. by Garrick V. Allen, Ian Paul and Simon P. Woodman}

[Die Offenbarung des Johannes. Strömungen in der britischen Forschung zur Apokalypse.]

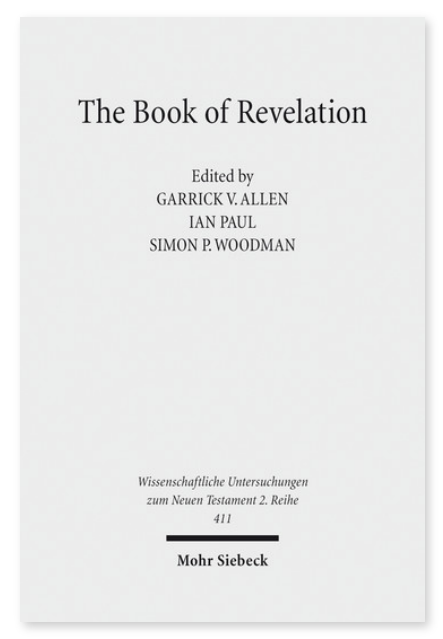

2015. XVIII, 336 Seiten. WUNT II 411

ISBN 978-3-16-153870-4 DOI 10.1628/978-3-16-153870-4 eBook PDF $104,00 €$

ISBN 978-3-16-153869-8 fadengeheftete Broschur 104,00€
Veröffentlicht auf Englisch.

Dieser Band präsentiert die Spannweite der Schwerpunkte in der aktuellen britischen Forschung zur Johannesoffenbarung und untersucht Fragen nach Genre, Aufbau, Komposition, Wiederverwendung der Schriften, Exegese, thematischen Problemen und der Rezeptionsgeschichte. Er enthält Beiträge von renommierten Wissenschaftlern sowie Nachwuchswissenschaftlerin und macht deren Erkenntnisse einer breiteren Leserschaft zugänglich. Inhaltlich leistet er einen Beitrag zu verschiedenen Diskussionen, nicht nur in Bezug auf die Apokalypse sondern auch auf allgemeinere Diskurse in Neuem Testament und frühem Christentum.

\section{Inhaltsübersicht}

Garrick V. Allen: Introducing The Book of Revelation: Currents in British Research on the Apocalypse

Text, Structure, and Persuasion

Garrick V. Allen: Reusing Scripture in the Book of Revelation: Techniques of Reuse and Habits of Reading - Andrew Harker: Prophetically Called Sodom and Egypt: The Affective Power of Revelation 11.1-13 - Ian Paul: Source, Structure, and Composition in the Book of Revelation

\section{Context, Interpretation, and Genre}

Richard Bauckham: Judgment in the Book of Revelation - Sarah Underwood Dixon: 'The Testimony of Jesus' in Light of Internal Self-References in the Books of Daniel and 1 Enoch - Sean Michael Ryan: 'The Testimony of Jesus' and 'The Testimony of Enoch': An emic Approach to the Genre of the Apocalypse - Michelle Fletcher: Apocalypse Noir: How Revelation Defined

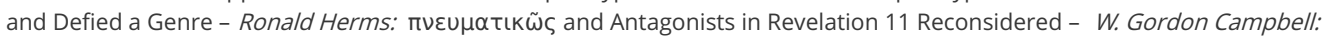
Facing Fire and Fury: One Reading of Revelation's Violence in the Context of Recent Interpretation - Simon P. Woodman: Fire from Heaven: Divine Judgment in the Book of Revelation - Paul Middleton: Male Virgins, Male Martyrs, Male Brides: A Reconsideration of the 144,000 'who have not dirtied themselves with women' (Revelation 14.4) - Shane J. Wood: God's Triumphal Procession: Re-examining the Release of Satan in the Light of Roman Imperial Imagery.

\section{Reception}

Christopher Rowland: British Interpretation of the Apocalypse: A Historical Perspective - lan Boxall: The Mighty Angel and the Little Scroll: A Reception-Historical Study of Revelation 10 - Jonathan Downing: The Women Clothed in the Sun: The Reception of Revelation 12 among Female British Prophets 1780-1814

\section{Afterword}

Steve Moyise: A Response to Currents in British Research on the Apocalypse

Garrick V. Allen Born 1988; 2015 PhD; Lecturer in New Testament Studies at Dublin City University, Republic of Ireland.

Ian Paul is Honorary Associate Professor at the University of Nottingham, Associate Minister at St Nicholas' Church, Nottingham and Managing Editor at Grove Books Ltd, Cambridge.

Simon P. Woodman is a former lecturer in Biblical Studies, a Baptist Minister, based at Bloomsbury Central Baptist Church, London and a Chaplain at King's College, London.

Jetzt bestellen:

https://mohrsiebeck.com/buch/the-book-of-revelation-9783161538704?no cache=1

order@mohrsiebeck.com

Telefon: +49 (0)7071-923-17

Telefax: +49 (0)7071-51104 